Japan. J. Med. Sci. Biol., 40, 119-130, 1987.

\title{
SEROEPIDEMIOLOGY OF HEPATITIS A VIRUS IN JAPAN
}

\author{
Jean TAYLOR-WIEDEMAN, Yasuo MORITSUGU1, Kikuko MIYAMURA \\ and Shudo YAMAZAKI
}

Central Virus Diagnostic Laboratory and 1Department of Enteroviruses, National Institute of Health, 4-7-1 Gakuen, Musashimurayama, Tokyo 190-12

(Received June 22, 1987. Accepted October 6, 1987)

SUMMARY: A seroepidemiologic study to detect class-specific antibody against hepatitis A virus (HAV) was made with 831 randomly collected sera (415 in 1973 and 416 in 1984) from healthy Japanese. Competitive-inhibition, IgG, IgA, and IgM anti-HAV enzyme-linked immunosorbent assays (ELISA) were used. Both collections showed a low prevalence of IgG anti-HAV in young age groups and it increased rapidly at middle age and plateued at $\geqq 94 \%$ prevalence in the older age groups. However, two age groups spanning ages 25-34 demonstrated statistically lower IgG anti-HAV age prevalences in 1984 vs $1973(\mathrm{P}<0.001)$, with an average 10 -year prevalence shift. These data suggest that there has been no significant level of HAV infection to alter antibody prevalences in Japan from 1973 to 1984. The markedly decreased incidence of HAV infection in Japan has created a presently large and growing population of HAV susceptibles.

\section{INTRODUCTION}

Incidence and prevalence of $\mathrm{HAV}$ infection in developed countries has decreased remarkably during the past two decades (1-7). In fact, in the United States where viral hepatitis incidence rates have been reported since 1952, even the 6 to 10-year periodicity of hepatitis A has disappeared along with declining annual incidence since $1970(7,8)$. These changes are due primarily to improved

J. ウイードマン・宮村紀久子・山崎修道 (国立予防衛生研究所ウイルス中央検査部 武蔵村山市学園4-7-1)

森次保雄 (国立予防衛生研究所腸内ウイルス部 武蔵村山市学園4-7-1) 
sanitation and hygienic conditions in developed countries, which interrupt the most common mechanism of transmission - serial transmission via fecal-oral route. In addition, there is no chronic fecal excretion or chronic viremia associated with HAV infection, nor epidemiologically important extra-human natural host (9). Therefore, there is no easily accessible pool of virus to readily infect susceptibles. Consequently, HAV epidemiology is changing in developed countries as represented in this report for Japan. By antibody class-specific ELISA for anti$\mathrm{HAV}$, we demonstrated a significant seroepidemiologic change that occurred form 1973 to 1984; specifically, a marked decrease in HAV infection incidence. Most likely, this change represents an ongoing trend in HAV seroepidemiology in Japan.

\section{MATERIALS AND METHODS}

Sera: All sera were obtained from the WHO Serum Reference Bank, NIH, Japan, Musashimurayama Annex. They were maintained at -70 C prior to testing and represented samples randomly collected from healthy individuals. The samples were divided into 5-year age groups beginning with ages $0-4,5-9,10-14$, etc., and ending with $50-54,55-59$, and $\geqq 60$ years old. All groups contained $31-33$ samples. The prefecture distribution included areas of north, central, and western Japan (Fig. 1). Sex distribution was comparable between respective 1973 and 1984 age groups by chi-square analysis (Table I).

Serology: ELISA methods were used to examine all sera (Table II). First, a competitive-inhibition ELISA (CI-ELISA) was used to assay for total anti-HAV. The CI-ELISA involves coating a polyvinylchloride (PVC) 96-well plate with a $10,000$-fold dilution of rat anti-HAV antibody (100 $\mathrm{\mu l} /$ well, overnight at $4 \mathrm{C})$, then $0.2 \%$ bovine serum albumin (BSA) post-coating ( $200 \mu \mathrm{l} /$ well, overnight at $4 \mathrm{C}$ ). BSA used in all assay methods was negative for anti-HAV. The next step was application of a highly purified inactivated $20 \mathrm{ng} / \mathrm{ml} \mathrm{HAV}$ antigen solution (50 $\mu \mathrm{l} /$ well, overnight at $4 \mathrm{C}$ ), while the blank wells received only $0.2 \% \mathrm{BSA}$ in phosphate buffered saline with $0.05 \%$ Tween 20 (PBS-T). Then a 64-fold dilution of a test serum was applied ( $50 \mu \mathrm{l} /$ duplicate wells, $30 \mathrm{~min}$ at room temperature), and (without removing the serum dilution) a 500-fold dilution of horseradish peroxidase (HRPO)-conjugated rabbit anti-HAV was simultaneously added (50 $\mathrm{\mu l} /$ well, $2 \mathrm{hr}$ at $37 \mathrm{C}$ ). Washing between the steps, except when conjugate was added, was repeated three times with PBS-T. The enzyme was then allowed to react with the usual substrate in a solution of $0.05 \mathrm{M}$ citrate buffer, $\mathrm{pH} 5$, containing $4 \mathrm{mg}$ orthophenylenediamine and $2 \mu \mathrm{l}$ of $30 \% \mathrm{H}_{2} \mathrm{O}_{2}$ per $10 \mathrm{ml}$ citrate buffer. Each well received $100 \mu$ l of the substrate and the reaction was allowed to 


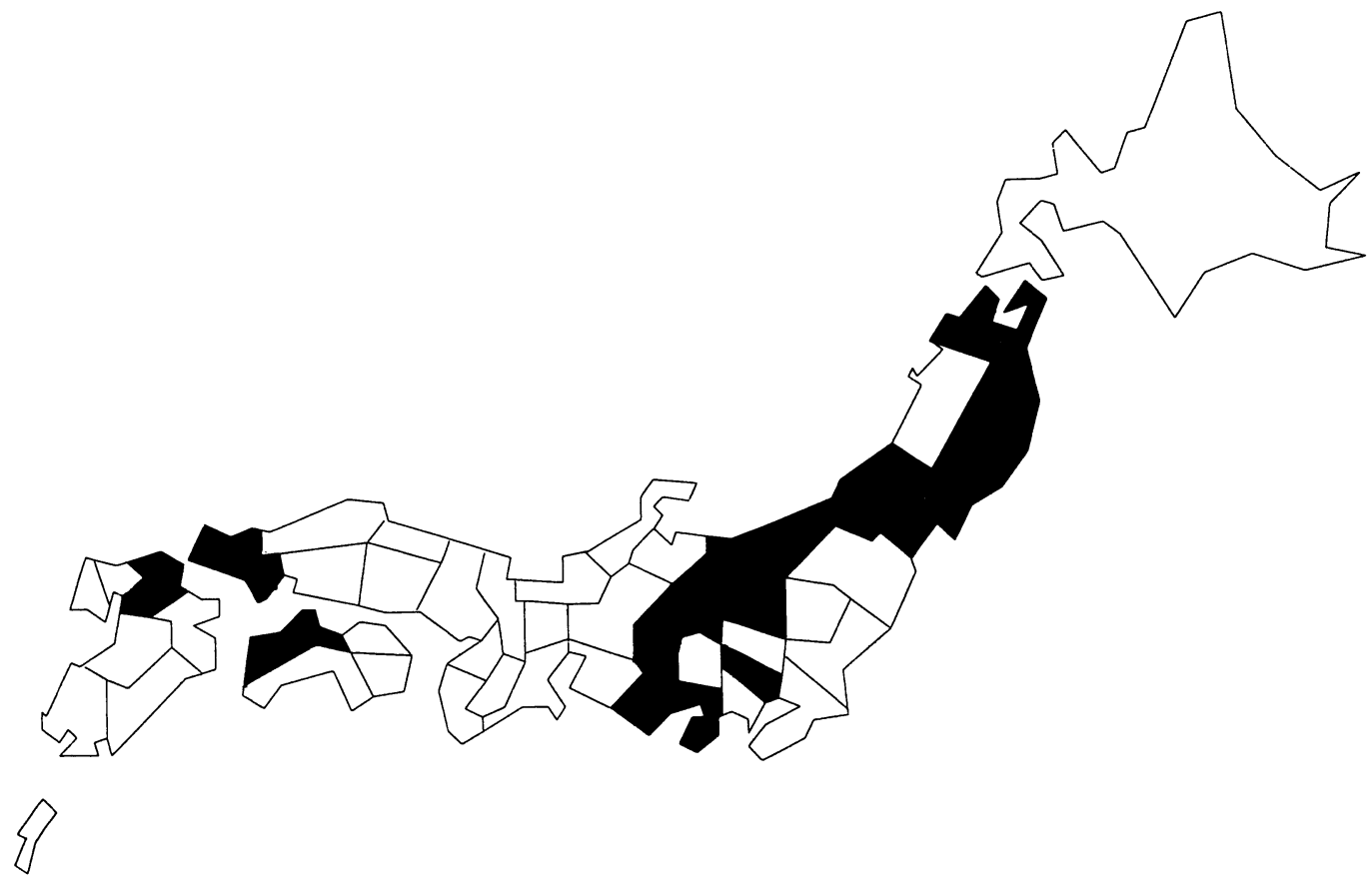

Fig. 1. Prefectural distribution of sera collected for HAV antibody analysis.

Table I. Age and sex distribution of test samples

\begin{tabular}{rrrrrrr}
\hline & \multicolumn{2}{c}{1973} & & \multicolumn{2}{c}{1984} & \\
\cline { 2 - 3 } \cline { 6 - 7 } Age & Male & Female & & Male & Female & Unknown \\
\hline $0-4$ & 17 & 15 & & 13 & 10 & 9 \\
$5-9$ & 18 & 14 & & 19 & 13 & 0 \\
$10-14$ & 25 & 7 & 21 & 12 & 0 \\
$15-19$ & 13 & 19 & & 12 & 11 & 8 \\
$20-24$ & 3 & 28 & 6 & 15 & 11 \\
$25-29$ & 8 & 25 & & 7 & 21 & 4 \\
$30-34$ & 11 & 21 & & 8 & 16 & 8 \\
$35-39$ & 13 & 19 & 12 & 14 & 6 \\
$40-44$ & 15 & 18 & 6 & 18 & 8 \\
$45-49$ & 10 & 21 & 13 & 12 & 7 \\
$50-54$ & 10 & 22 & 9 & 15 & 8 \\
$55-59$ & 13 & 18 & 10 & 14 & 8 \\
$\geqq 60$ & 14 & 18 & 6 & 18 & 8 \\
\hline Total & 170 & 245 & 142 & 189 & 85 \\
\hline
\end{tabular}


Table II. Methods of anti-HAV detection

\begin{tabular}{lllll}
\hline & $\begin{array}{l}\text { Competitive } \\
\text { ELISA } \\
\text { (Total) }\end{array}$ & $\begin{array}{c}\text { IgG } \\
\text { (Gamma) }\end{array}$ & $\begin{array}{c}\text { IgA } \\
\text { (Alpha) }\end{array}$ & $\begin{array}{c}\text { IgM } \\
(\mathrm{Mu})\end{array}$ \\
\hline $\begin{array}{l}\text { Capture } \\
\text { layer }\end{array}$ & Anti-HAV & Anti-HAV & $\begin{array}{l}\text { Anti-human } \\
\text { alpha }\end{array}$ & $\begin{array}{l}\text { Anti-human } \\
\mathrm{mu}\end{array}$ \\
$\begin{array}{l}\text { Step } \\
\# 1\end{array}$ & Inactivated & $\begin{array}{l}\text { Inactivated } \\
\text { HAV }\end{array}$ & Test serum & Test serum \\
$\begin{array}{l}\text { Step } \\
\# 2\end{array}$ & Test serum & Test serum & $\begin{array}{l}\text { Inactivated } \\
\text { HAV }\end{array}$ & $\begin{array}{l}\text { Inactivated } \\
\text { HAV }\end{array}$ \\
$\begin{array}{l}\text { Step } \\
\# 3\end{array}$ & $\begin{array}{l}\text { HRPO- } \\
\text { anti-HAV }\end{array}$ & $\begin{array}{l}\text { HRPO- } \\
\text { Protein A }\end{array}$ & $\begin{array}{l}\text { HRPO- } \\
\text { anti-HAV }\end{array}$ & $\begin{array}{l}\text { HRPO- } \\
\text { anti-HAV }\end{array}$ \\
\hline
\end{tabular}

proceed for $30 \mathrm{~min}$. The reaction was stopped with $2 \mathrm{M} \mathrm{H}_{2} \mathrm{SO}_{4}(100 \mathrm{\mu l} /$ well $)$ and optical density was read immediately at $492 \mathrm{~nm}$. Inhibition was expressed as percent of the optical density (OD) of a consistent laboratory reference negative serum (NS). The mean OD of four wells for the NS approximated a maximum optical density. Calculation of competitive inhibition rate (CIR) was as follows:

$$
\frac{\text { Mean OD of NS }- \text { Mean OD of test serum }}{\text { Mean OD of NS }} \times 100=\text { CIR }
$$

Each plate also included a consistent laboratory reference positive serum (approximate minimum OD) and the negative standard to judge the plate acceptability.

To specifically measure gamma-class anti-HAV, another ELISA was used (Table II). This assay used a similar PVC plate coated with a 50,000-fold dilution of chicken antibody against HAV $(100 \mathrm{\mu l} /$ well, overnight at $4 \mathrm{C})$, then $0.2 \% \mathrm{BSA}$ post-coating $(200 \mu 1 /$ well, overnight $4 \mathrm{C})$, followed by a highly purified inactivated $200 \mathrm{ng} / \mathrm{ml} \mathrm{HAV}$ antigen solution $(50 \mathrm{\mu l} / \mathrm{well}$, overnight at $4 \mathrm{C})$, a 200 -fold dilution of a test specimen $(50 \mathrm{\mu l} /$ paired wells, $1 \mathrm{hr}$ at $37 \mathrm{C})$, and a 16,000-fold dilution of HRPO-conjugated protein A ( $50 \mu \mathrm{l} /$ well, $1 \mathrm{hr}$ at $37 \mathrm{C})$. Washing between the steps was repeated three times with previously described wash solution. The substrate and stop solution were the same as those for CI-ELISA. Consistent positive and negative standards were used for each test plate. After spectrophotometric reading 
at $492 \mathrm{~nm}$, the results were expressed in optical density. This particular method of ELISA is successful because bird immunoglobulins are known to lack the receptor for binding Protein A. Therefore, the conjugated Protein A should bind selectively gamma-class human immunoglobulins only (10).

Finally, an antibody class-capture ELISA was used to examine specifically for the presence of either IgA and/or IgM antibodies (Table II). The assays were designed with a similar PVC plate, then a 10,000-fold dilution of mouse antihuman alpha or 10,000-fold dilution of mouse anti-human mu-specific monoclonal antibody captures $(100 \mu \mathrm{l} /$ well, overnight at $4 \mathrm{C})$ were applied. The next three steps (BSA post-coating, test serum, inactivated $\mathrm{HAV}$ antigen) were exactly the same as those for IgG ELISA. Finally, a 500-fold dilution of HRPO conjugated rabbit anti-HAV antibody ( $50 \mu \mathrm{l} /$ well, $1 \mathrm{hr}$ at $37 \mathrm{C})$ was added. Consistent positive and negative standards were used for each test plate. Washing, substrate and stop solutions were the same as those for the gamma-class anti-HAV ELISA. Plates were read at $492 \mathrm{~nm}$ and values were reported as optical density.

\section{RESULTS}

\section{Definition of Positive and Negative Sera}

CI-ELISA: For CI-ELISA, all sera in the 1973 and 1984 collections were plotted as percent inhibition versus number of observations (Fig. 2). An arbitrary cutoff for seronegative values was chosen as $<50 \%$ inhibition, values $>80 \%$ inhibition were considered seropositive, and those $\geqq 50 \%$ but $\leqq 80 \%$ were borderline.

IgG ELISA: For IgG ELISA, results were analyzed in a similar fashion to those of CI-ELISA (Fig. 3). Arbitrary cutoff OD values were also chosen: $<0.150$ for the seronegative values, $>0.250$ for the seropositive values, and $\geqq 0.150$ and $\leqq 0.250$ were considered borderline.

When CI-ELISA and IgG values were compared [excluding all $(\mathrm{N}=21)$ borderline values by either method], there was an excellent correlation. For the borderline CI-ELISA values, six sera were clearly positive by IgG ELISA, and these values were therefore considered seropositive. However, for the remaining seven borderline CI-ELISA sera, two were negative and the other five were borderline by IgG ELISA. All seven of these latter sera were excluded from further prevalence analysis. With such good correlation between two very different assay methods, the arbitrary cutoffs appeared to be accurate for defining positive and negative results. 


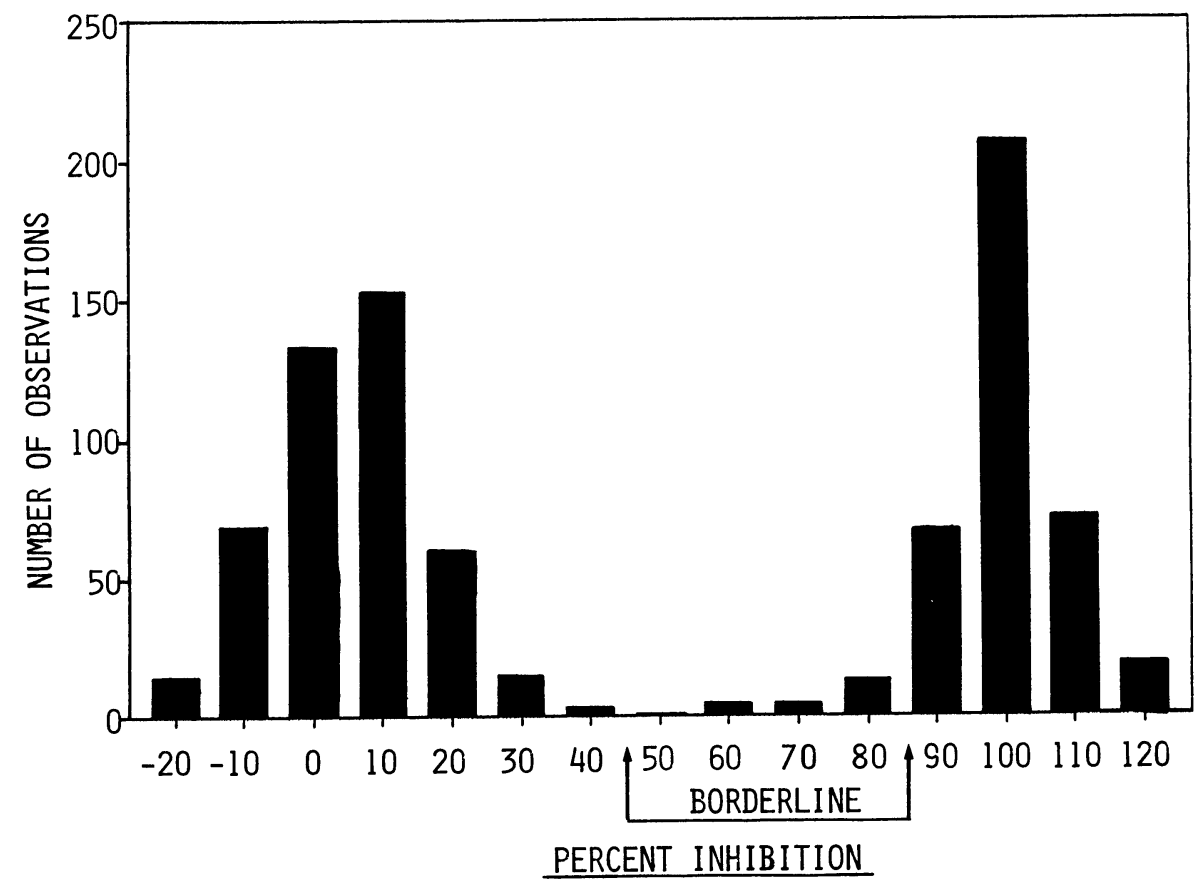

Fig. 2. Cumulative CI-ELISA results for 831 sera yielded a quite distinct two-peak distribution. The bell shaped distribution on the left represents seronegative values and that on the right represents seropositive values. Arbitrary seronegative $(<50 \%)$ and seropositive $(>80 \%)$ cutoff values were chosen. There were only 13 specimens $(1.6 \%)$ whose values were $\geqq 50 \%$ and $\leqq 80 \%$; they were considered borderline positive. In the latter 13 sera, IgA and IgM anti-HAV were negative and the ages of the individuals ranged from 30-66 for the 1973 collection and 38-75 for the 1984 collection.

IgA and IgM ELISA: For IgA and IgM anti-HAV, only HAV Ab-negative sera as determined by CI-ELISA were used to define the respective seronegative ranges. A total of 726 and 453 sera were plotted for IgA and IgM anti-HAV, respectively, and both formed a well-defined, bell-shaped distribution (data not shown). A mean and standard deviation (SD) were determined for each distribution; $\operatorname{IgA}=-0.025 \pm 0.030$, and $\operatorname{IgM}=-0.010 \pm 0.035$. Then $+4 \mathrm{SD}$ seronegative cutoff values were defined. For IgA, OD was 0.095 and for IgM 0.130 . 


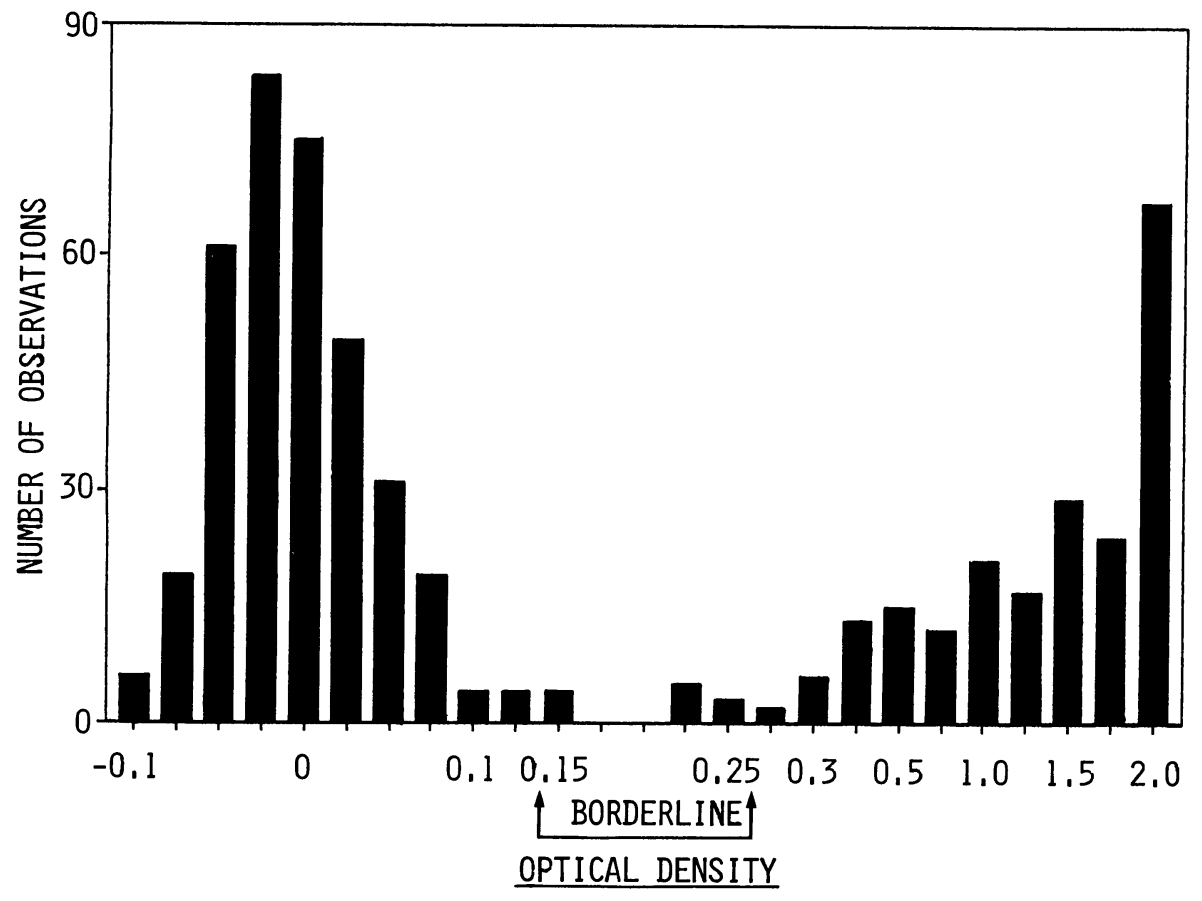

Fig. 3. Gamma class anti-HAV ELISA plotted as optical density vs number of observations. Representative sera $(\mathrm{N}=572)$ were analyzed; they were 359 CI-ELISA negative, 200 CI-ELISA positive, and all 13 of the borderline positive CI-ELISA values. Arbitrary seronegative $(<0.150 \mathrm{OD})$ and seropositive $(>0.250 \mathrm{OD})$ cutoffs were chosen. All optical densities $\geqq 0.150$ and $\leqq 0.250$ were considered borderline; this included 13 sera $(2.2 \%)$ of which 5 were also included in the previously described borderline positive CI-ELISA results.

\section{ELISA Specificity}

All sera that were negative in IgG anti-HAV or in CI-ELISA were also negative for IgA or IgM anti-HAV. All IgA-positive sera were positive for IgG anti-HAV. 


\section{Prevalence Analysis}

For the 1973 collection, the IgG anti-HAV data (Fig. 4) showed a low prevalence in the youngest age group (one 4-year-old child was seropositive), a return to $0 \%$ prevalence for ages $5-14$, then a low prevalence of IgG anti-HAV of only $9 \%$ at ages $15-19$ and $12 \%$ at ages $20-24$, and finally a steep incline in IgG prevalence after the mid-twenties which ultimately plateaued at $84-100 \%$ prevalence after 40-44 years of age. Coinciding with acquisition of IgG anti-HAV, that is after the age of 14 , there was an oscillating prevalence between $0-22 \%$ (mean $8 \%$ ) for IgA anti-HAV; while $0 \%$ prevalence was observed for IgM antiHAV.

For the 1984 collection, there was an even more striking shift of IgG antiHAV prevalence to older age such that all age groups prior to 30-34 were seronegative (Fig. 4). At 30-34 years of age, only 19\% showed IgG anti-HAV and following this there was a steep incline in IgG anti-HAV prevalence. By 45-49

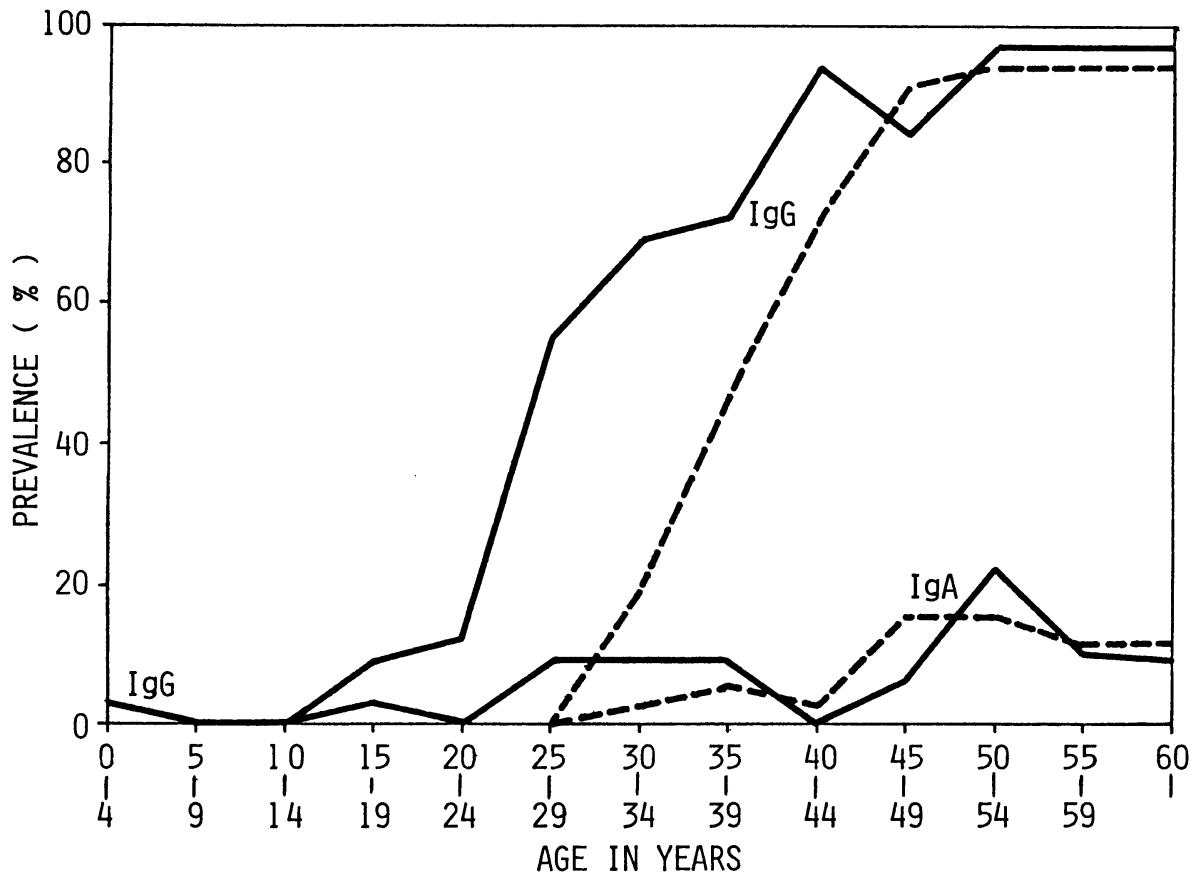

Fig. 4. Prevalence data for 1973, $N=415$ (solid line), and 1984, $N=$ 416 (dotted line), serum analyses. Only IgG and IgA results are shown. IgM prevalence $=0 \%$. 


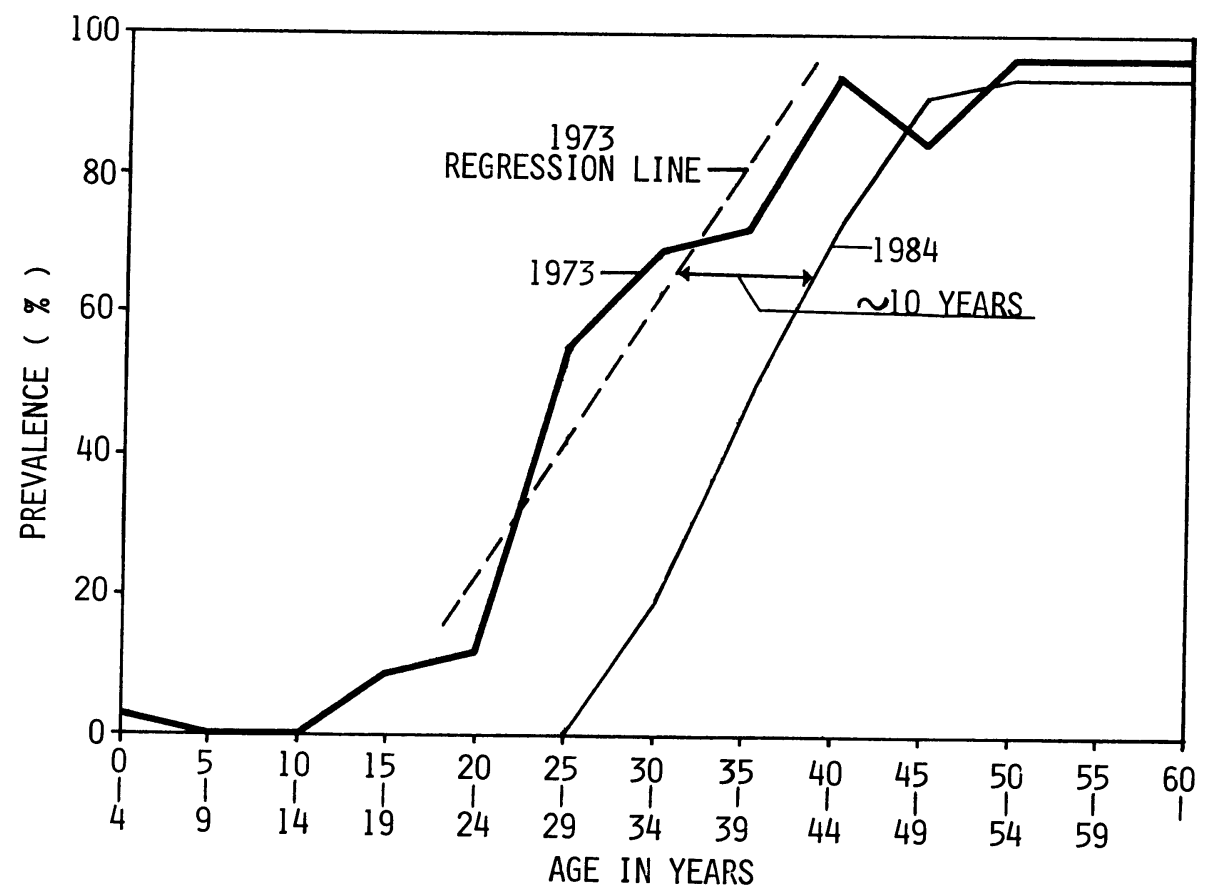

Fig. 5. The IgG-specific anti-HAV prevalence of the 1973 collection is compared with that of the 1984 collection. In 1973 , by ages $25-29,55 \%$ of the sample had IgG anti-HAV; whereas the respective 1984 group had $0 \%$ prevalence. Again, in 1973 at ages $30-34,68 \%$ of the sample had evidence of IgG-specific anti-HAV; while only $19 \%$ of the 1984 samples were seropositive for HAV. In both instances, chi-square analyses with Yates correction yielded significant $P$ values $<0.001$. In addition, the least squares method was used to calculate the 1973 regression line from the data points for the mid-portion of the curve only, which would be considered the straight segment of this sigmoid curve. The regression line for 1984 was so similar to the actual data that it was omitted. Comparison of the regression lines revealed an average shift of +10 years in anti-HAV prevalence.

years old, again, a plateau was observed where $90-97 \%$ of the population demonstrated IgG anti-HAV presence. For IgA anti-HAV there was a $0 \%$ prevalence prior to acquisition of IgG, then prevalences ranging 3-16\% (mean 10\%) for the older than 25-29 age groups were observed. Again, a 0\% IgM anti-HAV prevalence was noted. 
The 11-year separation between these two collections allowed age prevalence comparison over time (Fig. 5). Respective age-group results were analyzed by chisquare with Yates correction. $\mathrm{P}$ values were significant in both instances $(\mathrm{P}<0.001)$ for groups 25-29 and 30-34 years of age. When all other respective age groups were compared, there were no statistical differences. To examine the shift more closely, a superimposed dotted regression line at the midportion of the 1973 sigmoid prevalence curve is also seen in Fig. 5. From this graph, the 1984 antiHAV prevalence line is shifted to the right of the 1973 prevalence line by an average of 10 years.

\section{DISCUSSION}

In Japan, age-specific IgG prevalences demonstrated that young ages are no longer infected and it is only the older individuals (usually $\geqq 30-44$ years), who have at some time in their lives experienced HAV infection and therefore continue to show lifelong serum anti-HAV $(11,12)$. The same pattern of anti-HAV prevalence was reported by Moritsugu et al. (2) and Suzuki et al. (1) for healthy Japanese. In fact, Suzuki et al. (1) also noted a shifting of prevalence to older age groups when 1979 and 1982 serum collections were compared. The average +10 year shift of HAV sero-positivity noted in this report, coincides with the 11-year sample interval suggesting an extremely low incidence of HAV infection from 1973 to 1984 . Antibody class analysis revealed that IgM prevalences were $0 \%$ and mean IgA prevalences were $8 \%$ and $10 \%$ respectively for 1973 and 1984 . This also reinforces previous findings that acute infection occurred prior to collection of sera.

The age shift expands the population of susceptibles to include those at risk for greater morbidity due to HAV infection. Older individuals exhibit greater morbidity and frequency of clinical manifestations when infected with HAV virtually because of age (13-15). As well in Japan, there is a high incidence of hepatitis B virus (HBV) disease leading to other liver injury e.g., acute hepatitis, chronic hepatitis, cirrhosis, or primary hepatocellular carcinoma. For HBVinfected individuals, superimposed HAV hepatitis could potentially be devastating. Although some reports show that there is no cumulative morbidity, others have found that indeed patients who are chronic HbsAg carriers and who acquire superimposed acute $\mathrm{HAV}$ infection experience severer and more prolonged disease $(16,17)$. In addition, animals affected by simultaneous acute HAV and HBV infection suggests cumulative morbidity (18). Finally, in cases of such severe 
or progressive liver injury as cirrhosis, it has been reported that superimposed acute HAV infection can cause very serious disease leading to ascites and alteration of consiousness (19). Unfortunately, there is a paucity of information concerning simultaneous acute HAV infection and HBV chronic active hepatitis or primary hepatocellular carcinoma; one can only assume that such simultaneous insults would be very serious indeed.

Concerning the healthy population, for those Japanese individuals considering international travel to endemic areas, HAV immune status will become increasingly important. In Sweden, another population with a majority of susceptibles, it was found that from 0.2 to $1 \%$ of travelers to tropical Africa or Asia and the southern Mediterranean area contracted hepatitis A if they did not receive immune globulin prophylaxis (20). Hepatitis $A$ infection acquired abroad could be responsible for an unknown, all be it probably small, number of secondary domestic cases.

Finally, one must consider the population of child-bearing females who will no longer be able to transmit maternal HAV antibody to their offsprings. This may play an indirect role in viral transmission to other susceptibles. Neonatal nurseries, as well as child care centers caring for $<2-3$ year olds, are well recognized as high-risk areas for transmission of hepatitis A because these age groups are predominantly asymptomic with acute $\operatorname{HAV}$ infection $(11,14,21-23)$.

In the past, hepatitis A has been considered predominantly an infection of children. This is certainly no longer true in Japan. In the future, control of hepatitis A will require an awareness of epidemiologic change.

\section{ACKNOWLEDGEMENTS}

We are grateful to Mr. Toshio Ogino for his talented preparation of drawings.

\section{REFERENCES}

1. Suzuki, S., Tsuneya, Y. and Baba, M. (1984): Clin. Virol., 12, 150-153 (text in Japanese).

2. Moritsugu, Y., Tanaka, T. and Shikata, T. (1978): Japan. J. Med. Sci. Biol., $31,325-338$.

3. Pohjanpelto, P. and Lahdensivu, R. (1984): Scand. J. Infect. Dis., 16, 229-233. 
4. Hsu, H. Y., Chang, M. H., Chen, D. S., Lee, C. Y. and Sung, J. L. (1985): J. Med. Virol., 17, 297-301.

5. Committee on Epidemic Diseases, Ministry of Health, Singapore 0922 (1986): Epidemiol. News Bull., XII, 51-54.

6. Kremastinou, J., Kalapothaki, V. and Trichopoulos, D. (1984): Amer. J. Epidemiol., 120, 703-706.

7. Morbidity Mortality Weekly Report (Jan. 30, 1987): 36, 42-43.

8. McCollum, R. W. (1984): In A. S. Evans [ed.], Viral Infections of Humans. p.327-350. Plenum Publishing Corporation, New York.

9. Papaevangelou, G. J. (1984): In Robert J. Gerety [ed.], Hepatitis A. p.101132. Academic Press, Inc., Orlando, Florida.

10. Katz, D., Lehrer, S. and Kohn, A. (1985): J. Virol. Meth., 12, 59-70.

11. Hadler, S. C., Erben, J. J., Francis, D. P., Webster, H. M. and Maynard, J. E. (1982): J. Infect. Dis., 145, 255-261.

12. Friedman, L. S. and Dienstag, J. L. (1984): In Robert J. Gerety [ed.], Hepatitis A. p. 55-79. Academic Press, Inc., Orlando, Florida.

13. Decker, R. H., Overby, L. R., Ling, C. M., Frosner, G., Deinhardt, F. and Boggs, J. (1979): J. Infect. Dis., 139, 74-82.

14. Benenson, M. W., Takafuji, E. T., Bancroft, W. H., Lemon, S. M., Callahan, M. C. and Leach, D. A. (1980): Amer. J. Epidemiol., 112, 471-481.

15. Tabor, E. (1984): In Robert J. Gerety [ed.], Hepatitis A. p.47-53. Academic Press, Inc., Orlando, Florida.

16. Hindman, S. H., Maynard, J. E., Bradley, D. W., Berquist, K. R. and Denes, A. E. (1977): Amer. J. Epidemiol., 105, 135-139.

17. Sata, M., Beninger, P. R., Setoyama, H., Sakisaka, S., Hisanaga, H., Abe, H. and Tanikawa, K. (1981): Acta Hepatol. Japon., 22, 1654-1661 (text in Japanese).

18. Drucker, J., Tabor, E., Gerety, R. J., Jackson, D. and Barker, L. F. (1979): J. Infect. Dis., 139, 338-342.

19. Kumashiro, R., Sata, M., Setoyama, H., Maruyama, N., Hino, K., Yoshitake, M., Akashi, T., Gondo, K., Sano, Y., Rikitake, K., Kawaguchi, S., Abe, H. and Tanikawa, K. (1985): Acta Hepatol. Japon., 26, 1400-1406 (text in Japanese).

20. Christenson, B. (1985): Scand. J. Infect. Dis., 17, 5-10.

21. Hadler, S. C., Webster, H. M., Erben, J. J., Swanson, J. E. and Maynard, J. E. (1980): New Engl. J. Med., 302, 1222-1227.

22. Klein, B. S., Michaels, J. A., Rytel, M. W., Berg, K. G. and Davis, J. P. (1984): J. Amer. Med. Assoc., 252, 2716-2721.

23. Noble, R. C., Kane, M. A., Reeves, S. A. and Roeckel, I. (1984): J. Amer. Med. Assoc., 252, 2711-2715. 